\title{
Low-Temperature Synthesis and Catalytic Activity of Cobalt Ferrite in Nitrous Oxide $\left(\mathrm{N}_{2} \mathrm{O}\right)$ Decomposition Reaction
}

\author{
Kristina Denisova *, Alexander A. Ilyin (D), Ruslan Rumyantsev *, Julia Sakharova, Alexander P. Ilyin and \\ Natalya Gordina
}

check for updates

Citation: Denisova, K.; Ilyin, A.A.; Rumyantsev, R.; Sakharova, J.; Ilyin, A.P.; Gordina, N. Low-Temperature Synthesis and Catalytic Activity of Cobalt Ferrite in Nitrous Oxide $\left(\mathrm{N}_{2} \mathrm{O}\right)$ Decomposition Reaction. Catalysts 2021, 11, 889. https://doi.org/ $10.3390 /$ catal11080889

Academic Editors: Piotr Bartczak, Jaroslaw Polanski and

Tomasz Siudyga

Received: 28 April 2021

Accepted: 18 July 2021

Published: 22 July 2021

Publisher's Note: MDPI stays neutral with regard to jurisdictional claims in published maps and institutional affiliations.

Copyright: (c) 2021 by the authors. Licensee MDPI, Basel, Switzerland. This article is an open access article distributed under the terms and conditions of the Creative Commons Attribution (CC BY) license (https:// creativecommons.org/licenses/by/ $4.0 /)$.
Laboratory for Synthesis, Research and Testing of Catalytic and Adsorption Systems for Hydrocarbon Processing, Ivanovo State University of Chemistry and Technology, 153000 Ivanovo, Russia; ilyin@isuct.ru (A.A.I.); saxarova.s@yandex.ru (J.S.); ilyinap@isuct.ru (A.P.I.); gordina@isuct.ru (N.G.)

* Correspondence: kristi1992_1992@mail.ru (K.D.); rnr86@ya.ru (R.R.)

\begin{abstract}
Cobalt ferrite $\left(\mathrm{CoFe}_{2} \mathrm{O}_{4}\right)$ nanoparticles were synthesized and investigated as a catalyst in the reaction of nitrous oxide $\left(\mathrm{N}_{2} \mathrm{O}\right)$ decomposition. Cobalt ferrite was synthesized by solid-phase interaction at $1100{ }^{\circ} \mathrm{C}$ and by preliminary mechanochemical activation in a roller-ring vibrating mill at $400{ }^{\circ} \mathrm{C}$. The nanoparticles were characterized by X-ray diffraction (XRD), synchronous thermal analysis (TG and DSC) and scanning electron microscopy (SEM). A low-temperature nitrogen adsorption/desorption test was used to evaluate the catalytic activity of the cobalt ferrite nanoparticles. Correlations between the structure and catalytic properties of the catalysts are reported. The highest catalytic activity of $\mathrm{CoFe}_{2} \mathrm{O}_{4}$ in the reaction of nitrous oxide decomposition was $98.1 \%$ at $475{ }^{\circ} \mathrm{C}$ for cobalt ferrite obtained by mechanochemical activation.
\end{abstract}

Keywords: cobalt ferrite; mechanochemical synthesis; iron oxalate; cobalt oxalate; nitrous oxide; decomposition; catalyst

\section{Introduction}

Cobalt ferrite attracts the attention of many researchers for its unique properties that allow this compound to be used in various industries. Nanoparticles of cobalt ferrite are widely used as magnetic materials [1,2], biosensors [3], ferromagnetic fluids [4,5], catalysts, and photocatalysts [6,7].

It is known that materials used in different industries must have different properties. Ferrites, used as catalysts, should have a high surface area and a developed porous structure, as well as the necessary combination of structural and mechanical properties. These properties of the product mainly depend on the method of its synthesis. For the cobalt ferrite synthesis, various methods are used: solid-phase synthesis [8,9], co-precipitation [10], hydrothermal [11,12] and sol-gel synthesis [13,14], the Massart method [15], and microwave synthesis [16,17]. These methods have some drawbacks. Thus, solid-phase synthesis requires high temperatures and long calcination, which does not allow obtaining the product in a highly dispersed state. Methods based on obtaining ferrites from salt solutions are very laborious and multistage. They require strict control of the parameters of the process (temperature, $\mathrm{pH}$, etc.), and there are large amounts of wastewater. Mechanochemical synthesis allows excluding most of these disadvantages. This simple and fast method of synthesis makes it possible to obtain a large amount of nanostructured powder [18,19]. There are some data about the mechanochemical synthesis of different ferrites [20-24]. Cobalt ferrite nanoparticles are proposed to be obtained by two-stage mechanochemical synthesis [24,25]: co-precipitation and subsequent mechanochemical grinding of co-precipitated precursors. $\mathrm{Cu}-\mathrm{Co}$ ferrites are obtained by a similar method [25]. Cobalt ferrite supported on $\mathrm{SiO}_{2}$ [20] is proposed to be produced by a joint mechanical activation and further heat treatment of the $6 \mathrm{Fe}_{2} \mathrm{O}_{3}-2 \mathrm{Co}_{3} \mathrm{O}_{4}$-Si system. $\mathrm{CoFe}_{2} \mathrm{O}_{4}$ is also obtained by mechanical grinding of previously prepared layered double cobalt hydroxycarbonate $\left(\mathrm{CoFe}_{2}(\mathrm{OH})_{4}\left(\mathrm{CO}_{3}\right)_{2} \cdot \mathrm{nH}_{2} \mathrm{O}\right)[19]$. 
Calcium hydroxide $\left(\mathrm{Co}(\mathrm{OH})_{2}\right)$ and iron oxalate $\left(\mathrm{FeC}_{2} \mathrm{O}_{4} \cdot 2 \mathrm{H}_{2} \mathrm{O}\right)$ are used as precursors for the mechanochemical synthesis of cobalt ferrite [23]. Analysis of the methods for obtaining highly dispersed cobalt ferrites under nonequilibrium conditions shows that the use of mechanochemical synthesis leads to the formation of crystalline cobalt ferrite.

As noted earlier, ferrites are widely used in catalysis. They are catalysts for a number of processes, such as the catalytic oxidation of chlorobenzene [6], the decomposition of cyclohexane [26], the dehydration of ethylbenzene [27], the oxidation of alkenes [28], etc. A promising direction of their use is the process of gas emissions neutralizing, since they can successfully replace the catalysts containing noble metals such as platinum, palladium, or gold [29].

These facts make cobalt ferrite a promising material that can be widely used. However, there is a lack of data on the effect of precursors on the formation of the crystalline phase of cobalt ferrite and its physicochemical and catalytic properties.

Therefore, the aim of the investigation was to study the system $\mathrm{CoC}_{2} \mathrm{O}_{4} \cdot 2 \mathrm{H}_{2} \mathrm{O}$ $\mathrm{FeC}_{2} \mathrm{O}_{4} \cdot 2 \mathrm{H}_{2} \mathrm{O}$ during mechanical activation and heat treatment, as well as to identify the structural, physicochemical and catalytic properties of the cobalt ferrites in the $\mathrm{N}_{2} \mathrm{O}$ decomposition reaction.

\section{Results}

Low-temperature production of ferrites from Co and Fe metal oxalates. The calcination of a mixture of iron and cobalt oxalates subjected to mechanical activation at a temperature of $300{ }^{\circ} \mathrm{C}$.

Since the temperature of $\mathrm{CoFe}_{2} \mathrm{O}_{4}$ formation is low, a developed porosity and a high specific surface area should be expected.

Cobalt ferrite exhibits high catalytic activity in the decomposition reaction of nitric oxide (I).

\section{Discussion}

\subsection{Structural Characteristics of the Reagents}

On the basis of X-ray phase analysis, it is found that the process of mechanical activation from 1 to $45 \mathrm{~min}$ is accompanied by a gradual decrease in the integral intensity of the reflections of the iron oxalate phase, which indicates its amorphization. In addition, the size of the iron oxalate crystallites decreases from $195 \AA$ (for the original $\mathrm{FeC}_{2} \mathrm{O}_{4} \cdot 2 \mathrm{H}_{2} \mathrm{O}$ ) to $88 \AA$ After $45 \mathrm{~min}$ of mechanical activation. On the contrary, the microstrain value increases from 0.1 to $0.82 \%$ (Table 1). It is necessary to note that the size of coherent scattering region (CSR) is smaller than the crystallite size, since it does not include the outer amorphized crystallite layers, and the microstrain value includes all lattice distortions caused by point (Frenkel and Schottky defects) and linear (edge and screw dislocations) and other types of defects [30]. Characteristic reflections of cobalt oxalate are not observed, this fact indicates its amorphous state. The formation of new phases at the stage of mechanical activation is not recorded.

Table 1. Changes in the size of crystallites and the microstrain value of iron oxalate.

\begin{tabular}{ccccc}
\hline & \multicolumn{4}{c}{ Mechanical Activation Time, min } \\
\cline { 2 - 5 } & $\mathbf{1}$ & $\mathbf{1 5}$ & $\mathbf{3 0}$ & $\mathbf{4 5}$ \\
\hline $\mathrm{D}_{\mathrm{SCR}, \AA}$ & 186 & 177 & 160 & 108 \\
\hline$\varepsilon, \%$ & 0.26 & 0.41 & 0.65 & 0.82 \\
\hline $\mathrm{E}, \mathrm{kJ} / \mathrm{g}$ & 1.5 & 26.5 & 53 & 80 \\
\hline
\end{tabular}

The distributions of particle sizes of the initial components and products of mechanical activation are presented in Figure 1. The mixture subjected to mechanical activation consists mainly of particles of size up to $3 \mu \mathrm{m}$, from 3 to $25 \mu \mathrm{m}$ and from 25 to $160 \mu \mathrm{m}$. The nature 
of the particle size distribution indicates that in the process of intensive mechanical actions, the minimum particle size is reached quickly, and the grinding process practically stops. The aspiration of the system to decrease the excess of free energy leads to the prevalence of secondary aggregation processes. Thus, the microstructure of the product is formed as a result of two opposite processes: reducing the size of individual particles during their destruction, and the formation of aggregates from these particles [31,32].

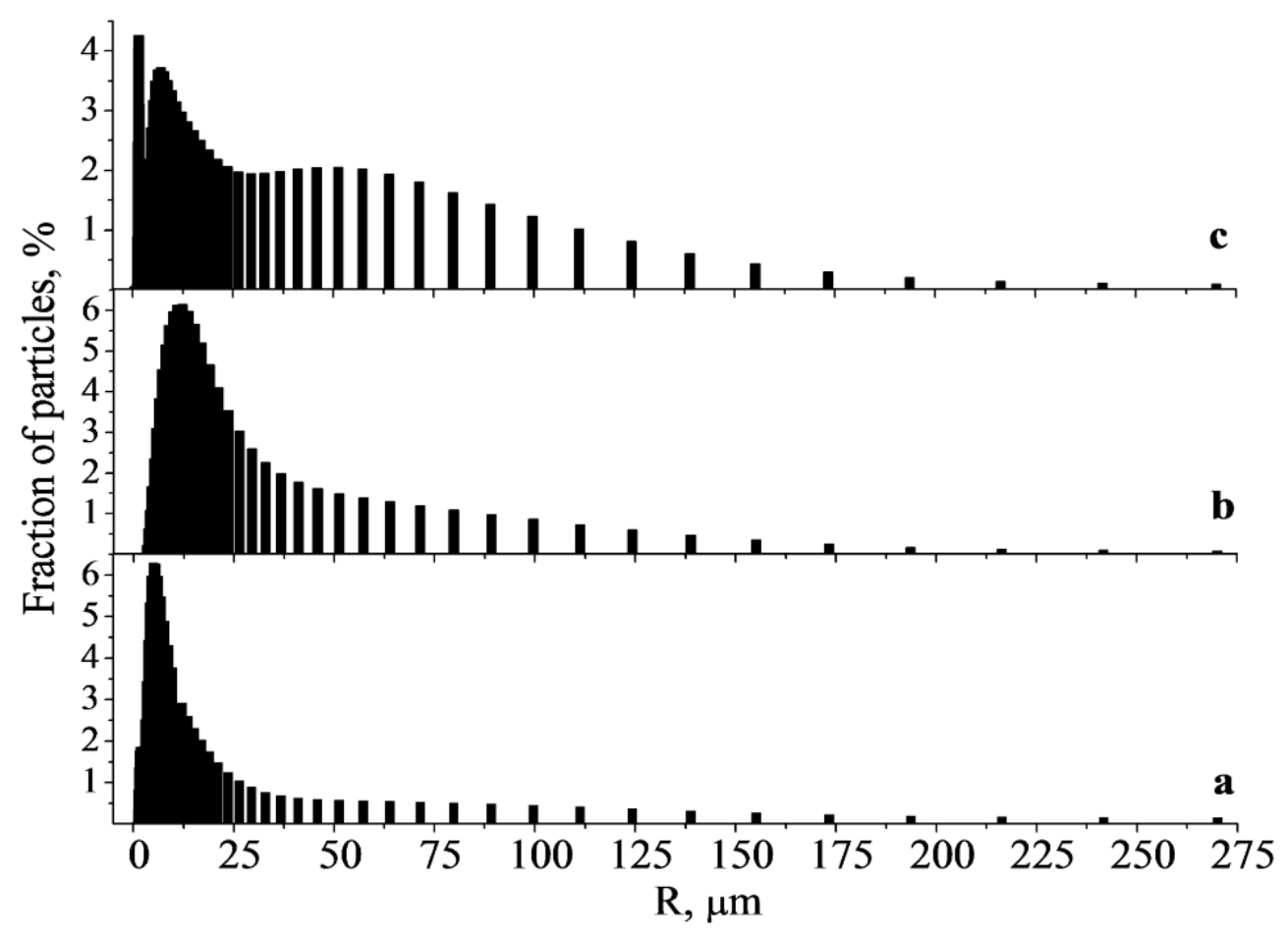

Figure 1. The particle size distribution of $\mathrm{CoC}_{2} \mathrm{O}_{4} \cdot 2 \mathrm{H}_{2} \mathrm{O}(\mathrm{a}), \mathrm{FeC}_{2} \mathrm{O}_{4} \cdot 2 \mathrm{H}_{2} \mathrm{O}(\mathrm{b})$ and their mixture (c) subjected to mechanical activation for $45 \mathrm{~min}$.

\subsection{Samples Thermal Behavior}

The calcination of a mixture of iron and cobalt oxalates subjected to mechanical activation at a temperature of $300{ }^{\circ} \mathrm{C}$ leads to the appearance of the $\gamma-\mathrm{Fe}_{2} \mathrm{O}_{3}$ phase (Figure 2 (a)). An increase in calcination temperature to $350^{\circ} \mathrm{C}$ (Figure $2(\mathrm{~b})$ ) does not lead to significant changes. However, the temperature increasing up to $400{ }^{\circ} \mathrm{C}$ leads to the appearance of a group of reflections which are characteristic for cobalt ferrite. Calcination of the samples at $450{ }^{\circ} \mathrm{C}$ leads to an increase in integral intensity of the $\mathrm{CoFe}_{2} \mathrm{O}_{4}$ reflections (Figure 2 (c)), so the ongoing crystallization processes are observed.

XRD patterns of the calcined samples prepared by solid-phase synthesis without preliminary mechanochemical treatment are shown in Figure $3(\mathrm{a}-\mathrm{d})$. Calcination at $300{ }^{\circ} \mathrm{C}$ leads to the decomposition of iron and cobalt oxalates and formation of amorphous mixture of iron and cobalt oxides, respectively (Figure 3 (a)). Heat treatment at $350{ }^{\circ} \mathrm{C}$ leads to the appearance of reflections characteristic for $\gamma-\mathrm{Fe}_{2} \mathrm{O}_{3}$, which indicates its crystallization (Figure $3(\mathrm{~b})$ ). An increase in temperature to $450{ }^{\circ} \mathrm{C}$ leads to a transition of $\gamma-\mathrm{Fe}_{2} \mathrm{O}_{3}$ to $\alpha-\mathrm{Fe}_{2} \mathrm{O}_{3}$ and the appearance of a crystalline phase of cobalt oxide $\mathrm{Co}_{3} \mathrm{O}_{4}$ (Figure 3 (c)). Further calcination at a temperature of $450-850{ }^{\circ} \mathrm{C}$ leads only to crystallization of iron and cobalt oxides (Figure $3(\mathrm{~d}, \mathrm{e})$ ). The formation of monophasic cobalt ferrite is observed only at a temperature of $1100{ }^{\circ} \mathrm{C}$ (Figure $\left.3(\mathrm{f})\right)$. 


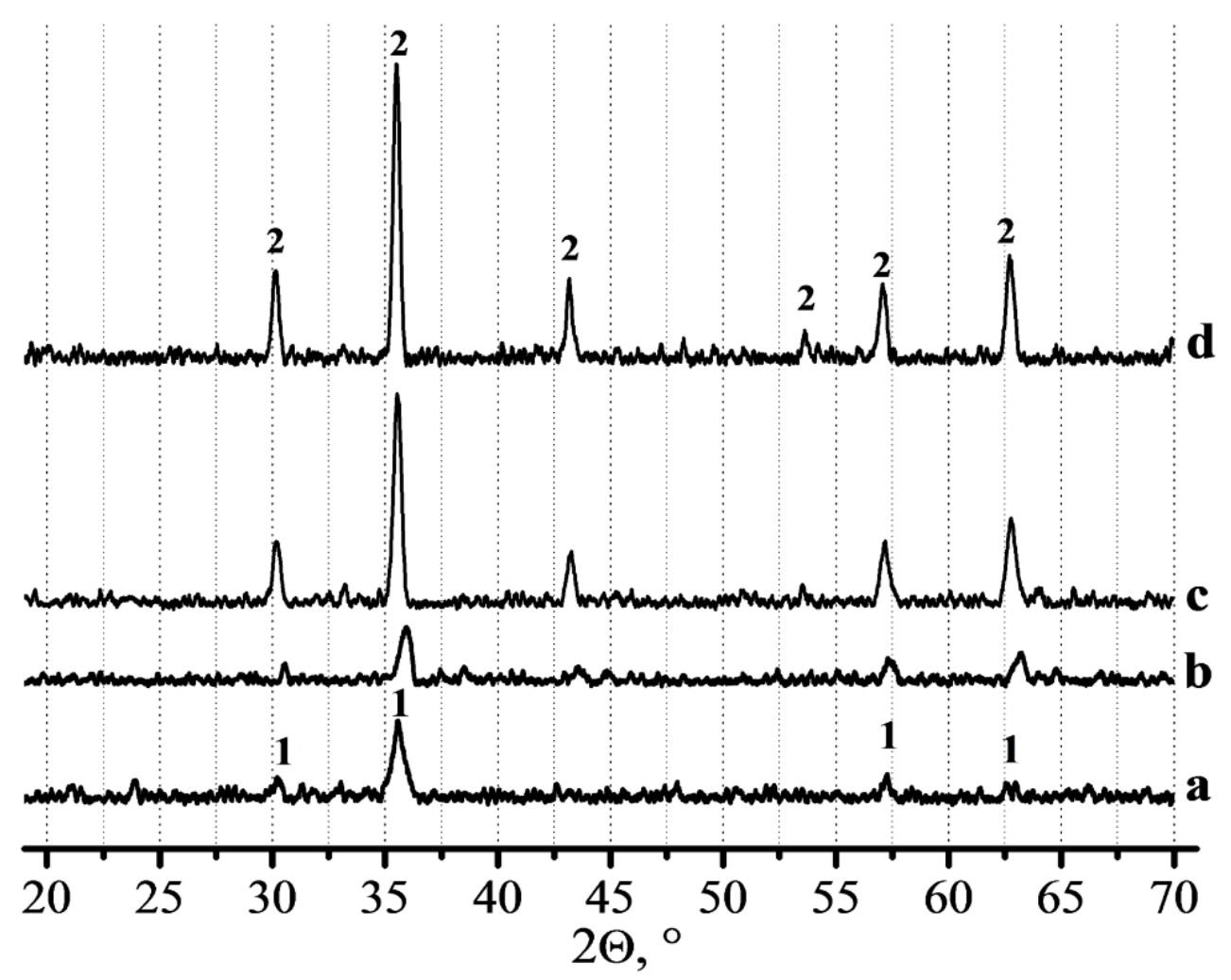

Figure 2. XRD patterns of products of mechanochemical activation of $\mathrm{FeC}_{2} \mathrm{O}_{4} \cdot 2 \mathrm{H}_{2} \mathrm{O}$ and $\mathrm{CoC}_{2} \mathrm{O}_{4} \cdot 2 \mathrm{H}_{2} \mathrm{O}$ subjected to heat treatment at the temperatures, ${ }^{\circ} \mathrm{C}: \mathrm{a}-300, \mathrm{~b}-350, \mathrm{c}-450, \mathrm{~d}-500$; $1-\gamma-\mathrm{Fe}_{2} \mathrm{O}_{3} ; 2-\mathrm{CoFe}_{2} \mathrm{O}_{4}$.

Calcination of the sample obtained by solid-phase synthesis without prior preliminary mechanochemical treatment is accompanied by six thermal effects (Figure 4 (a)). Zone $\mathrm{I}$ - endothermic effect, lying in the temperature range of $130-215{ }^{\circ} \mathrm{C}$, is associated with the removal of crystallization water. Zones II and III- exothermic effects that lie in the temperature ranges of $215-255^{\circ} \mathrm{C}$ and $265-295^{\circ} \mathrm{C}$. They are associated with the decomposition of iron and cobalt oxalates, as well as simultaneous carbon monoxide oxidation:

$$
\begin{gathered}
2 \mathrm{FeC}_{2} \mathrm{O}_{4}(\mathrm{~s})+0.5 \mathrm{O}_{2} \rightarrow \mathrm{Fe}_{2} \mathrm{O}_{3}(\mathrm{~s})+2 \mathrm{CO}+2 \mathrm{CO}_{2}(\mathrm{~g}) \uparrow \\
3 \mathrm{CoC}_{2} \mathrm{O}_{4}(\mathrm{~s}) \rightarrow \mathrm{Co}_{3} \mathrm{O}_{4}(\mathrm{~s})+4 \mathrm{CO}+2 \mathrm{CO}_{2}(\mathrm{~g}) \uparrow
\end{gathered}
$$

Zone IV-exothermic effect, lying in the temperature range of $350-410{ }^{\circ} \mathrm{C}$, is due to the transition of $\gamma-\mathrm{Fe}_{2} \mathrm{O}_{3}$ to $\alpha-\mathrm{Fe}_{2} \mathrm{O}_{3}$. Zone $\mathrm{V}$-endothermic effect, observed in the temperature range of $900-940{ }^{\circ} \mathrm{C}$, is associated with decomposition of cobalt oxide $\mathrm{Co}_{3} \mathrm{O}_{4}$ :

$$
\mathrm{Co}_{3} \mathrm{O}_{4} \rightarrow 3 \mathrm{CoO}+0.5 \mathrm{O}_{2}
$$

The TG curve of this sample (Figure 5 (a)) shows clearly pronounced step-wise mass losses due to the removal of crystallization water, decomposition of oxalates, and oxygen emissions from the $\mathrm{Co}_{3} \mathrm{O}_{4}$ structure. 


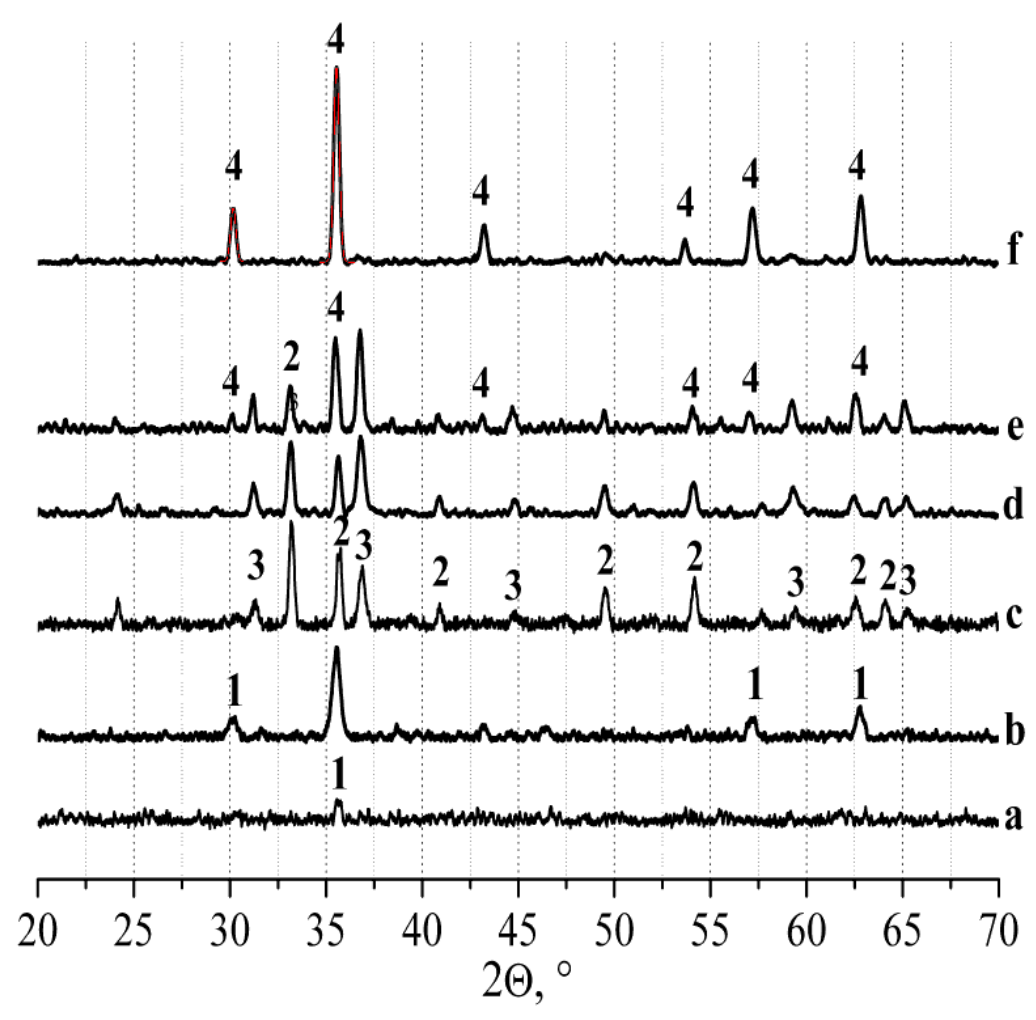

Figure 3. $\mathrm{XRD}$ patterns of the products of heat treatment of a mixture of $\mathrm{FeC}_{2} \mathrm{O}_{4} \cdot 2 \mathrm{H}_{2} \mathrm{O}$ and $\mathrm{CoC}_{2} \mathrm{O}_{4} \cdot 2 \mathrm{H}_{2} \mathrm{O}$ at the temperatures, ${ }^{\circ} \mathrm{C}: \mathrm{a}-300, \mathrm{~b}-350, \mathrm{c}-450, \mathrm{~d}-500, \mathrm{e}-850, \mathrm{f}-1100 ; 1-\gamma-\mathrm{Fe}_{2} \mathrm{O}_{3}$; $2-\alpha-\mathrm{Fe}_{2} \mathrm{O}_{3} ; 3-\mathrm{Co}_{3} \mathrm{O}_{4} ; 4-\mathrm{CoFe}_{2} \mathrm{O}_{4}$.

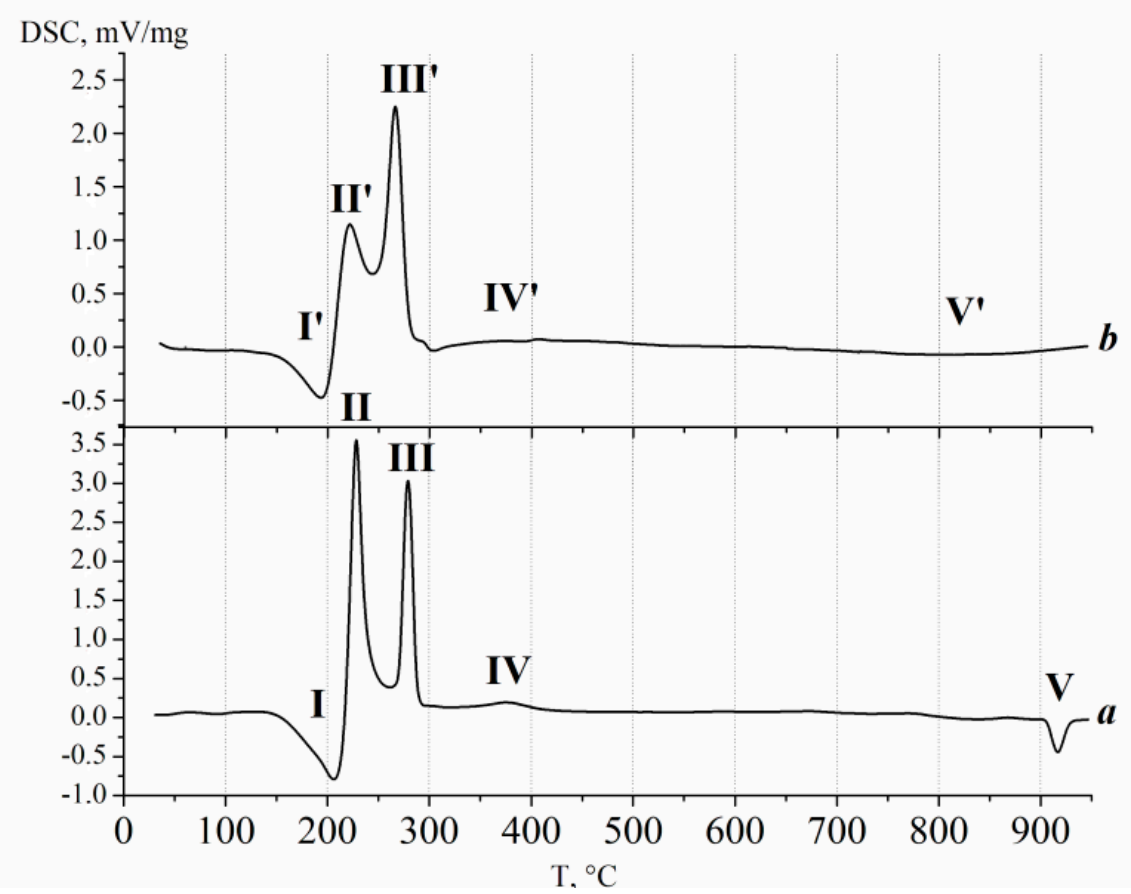

Figure 4. DSC curves of a mixture of $\mathrm{FeC}_{2} \mathrm{O}_{4} \cdot 2 \mathrm{H}_{2} \mathrm{O}$ and $\mathrm{CoC}_{2} \mathrm{O}_{4} \cdot 2 \mathrm{H}_{2} \mathrm{O}$ without preliminary treatment (a) and after mechanical activation for $45 \mathrm{~min}$ (b). 


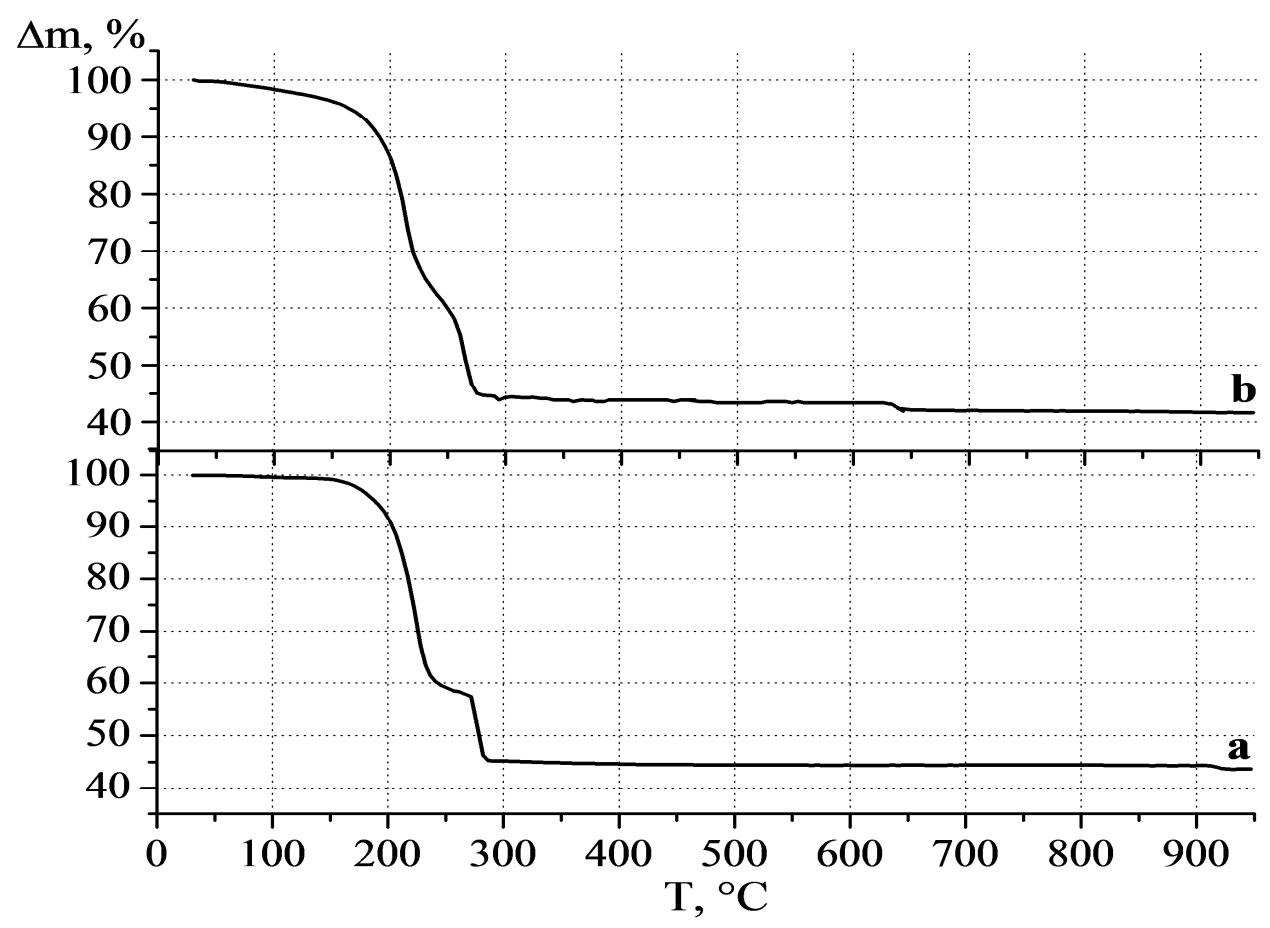

Figure 5. TG curves of a mixture of $\mathrm{FeC}_{2} \mathrm{O}_{4} \cdot 2 \mathrm{H}_{2} \mathrm{O}$ and $\mathrm{CoC}_{2} \mathrm{O}_{4} \cdot 2 \mathrm{H}_{2} \mathrm{O}$ without preliminary treatment (a) and after mechanical activation for $45 \mathrm{~min}(\mathrm{~b})$.

The mechanochemical activation of the oxalates mixture leads to a change in the shape of the DSC curve (Figure 4 (b)). The thermal effects of the decomposition of iron oxalate (II) and cobalt (II) oxalates are shifted by 8 and $12{ }^{\circ} \mathrm{C}$, respectively, towards lower temperatures. Gradual mass loss is also observed on the TG curve, but it has a flatter form. The IV thermal effect lying in the temperature range of $300-525^{\circ} \mathrm{C}$ is caused by the ongoing crystallization of cobalt ferrite $\left(\mathrm{CoFe}_{2} \mathrm{O}_{4}\right)$. The endothermic effect in the temperature range of $650-900{ }^{\circ} \mathrm{C}$ is due to the emission of oxygen from $\mathrm{CoFe}_{2} \mathrm{O}_{4}$ structure, as further indicated by the mass loss observed on the TG curve (Figure 5 (b)). Obviously, when mechanically activating, along with grinding and intensive mixing, there is also the accumulation of excess energy in the form of defects in the crystal structure. This helps to reduce the temperature of decomposition of the initial components and the temperature of formation of the product—cobalt ferrite.

\subsection{Morphology and Structural Characteristics}

The synthesized cobalt ferrites obtained by the method of mechanochemical synthesis (Figure 6) are characterized by a hierarchical structure and consist of spherical particles with a size of $0.1 \mu \mathrm{m}$. Spherical nanocrystals agglomerate into larger porous particles of regular spherical shape with a size of 5-25 $\mu \mathrm{m}$ (Figure 6a).

An increase in the calcination temperature leads to an increase in the size of both the particles themselves and the aggregates they formed (Figure 6b). The cobalt ferrite obtained by the solid-phase synthesis without preliminary mechanochemical activation (Figure 6c) consists of spherical particles with pronounced morphology. Their size changes from 2.5 to $5 \mu \mathrm{m}$. A high heat treatment temperature $\left(1100^{\circ} \mathrm{C}\right)$ leads to sintering of the particles into larger aggregates (Figure 6c).

Table 2 summarizes the characteristics of cobalt ferrites obtained by mechanochemical and solid-phase methods. 

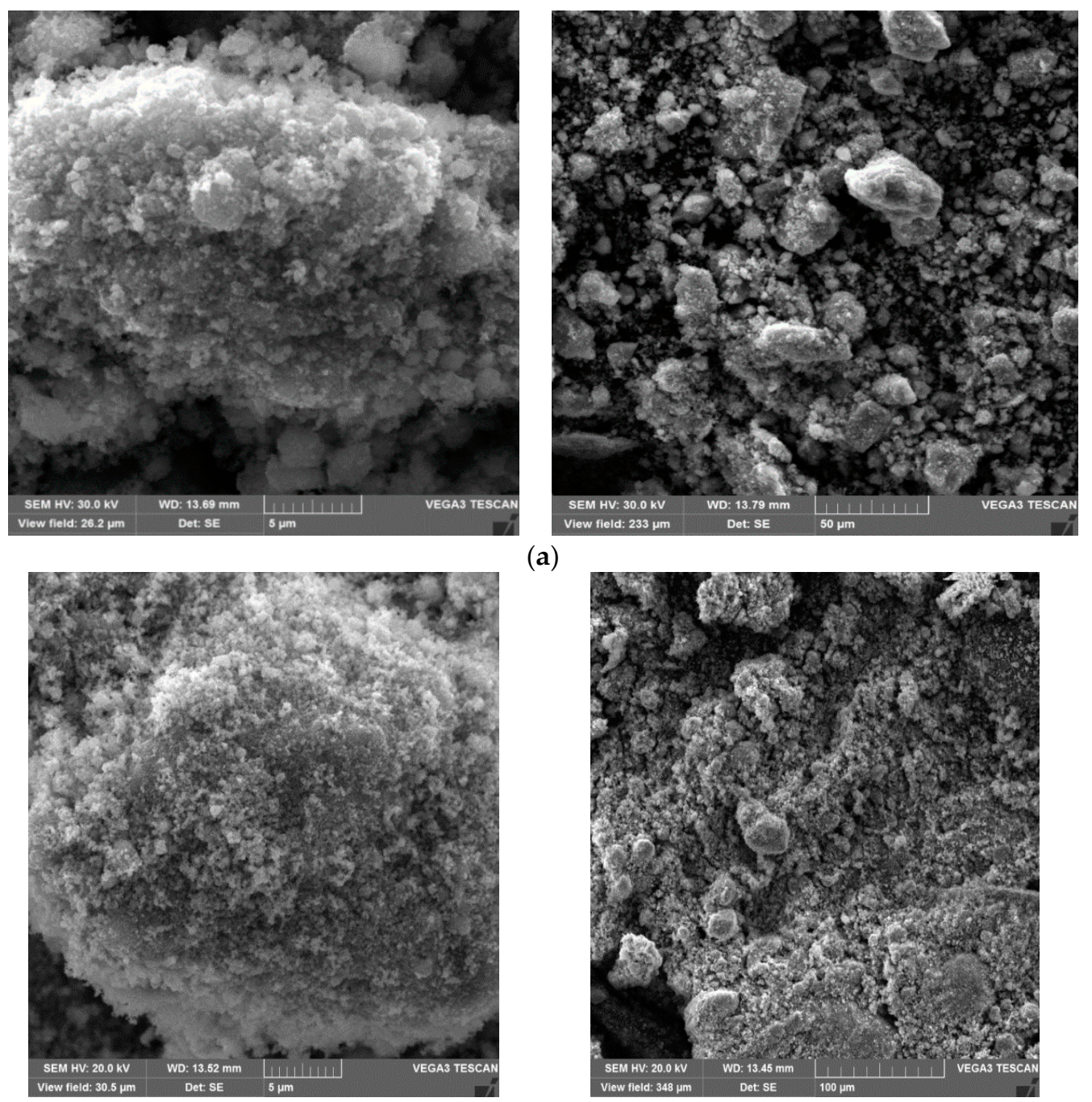

(a)
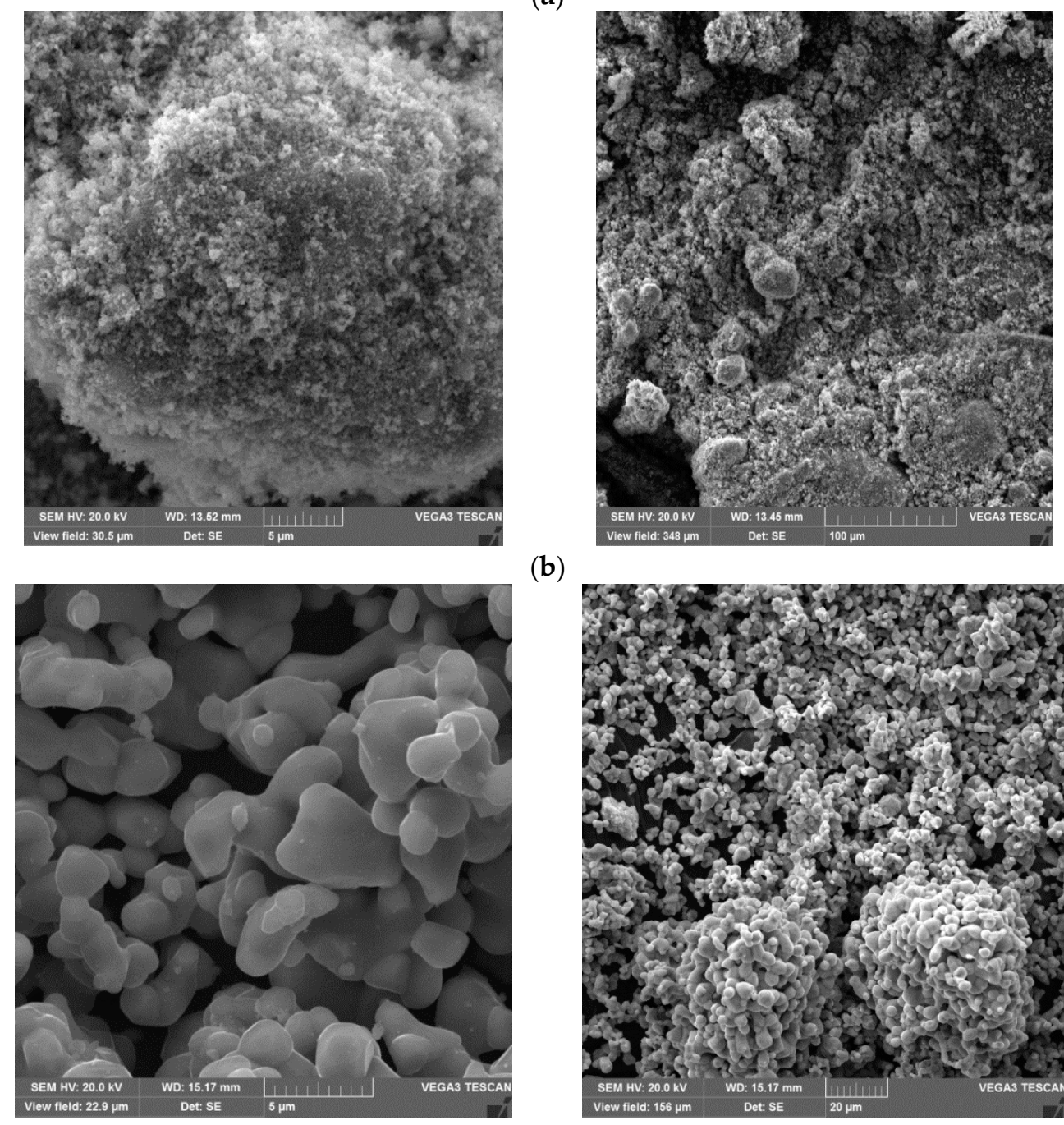

(b)

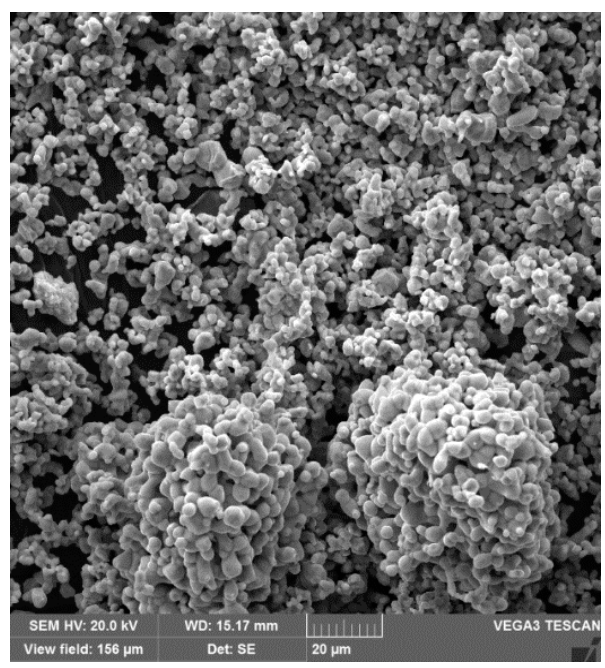

(c)

Figure 6. SEM images of cobalt ferrites obtained at the temperatures, ${ }^{\circ} \mathrm{C}$ (mechanochemical synthesis $(\mathbf{a}, \mathbf{b})$, solid phase synthesis (c)): (a) - 350, (b)—450, (c) - 1100 . 
Table 2. Characteristics of cobalt ferrites obtained by various methods.

\begin{tabular}{|c|c|c|c|c|}
\hline \multirow[b]{3}{*}{ Heat treatment temperature, ${ }^{\circ} \mathrm{C}$} & \multicolumn{4}{|c|}{ Synthesis Method } \\
\hline & \multicolumn{3}{|c|}{ Mechanochemical } & \multirow{2}{*}{$\begin{array}{c}\text { Solid-Phase } \\
1100\end{array}$} \\
\hline & 350 & 400 & 450 & \\
\hline Heat treatment time, min & 300 & 300 & 300 & 360 \\
\hline Phase composition & \multicolumn{4}{|c|}{$\mathrm{CoFe}_{2} \mathrm{O}_{4}$} \\
\hline Lattice parameter a, $\AA$ & 8288 & 8378 & 8377 & 8390 \\
\hline Specific surface area $\mathrm{S}_{\mathrm{SSA}}, \mathrm{m}^{2} / \mathrm{g}$ & 78.9 & 34.2 & 15.4 & 0.6 \\
\hline $\mathrm{D}_{\mathrm{CSR}}, \AA$ & 175 & 264 & 299 & 310 \\
\hline Microstrain value $\varepsilon, \%$ & 0.38 & 0.30 & 0.21 & 0.10 \\
\hline Total pore volume, $\mathrm{cm}^{3} / \mathrm{g}$ & 0.151 & 0.063 & 0.023 & - \\
\hline
\end{tabular}

Cobalt ferrite has a cubic crystal lattice with, according to the database [33], parameters $\mathrm{a}=\mathrm{b}=\mathrm{c}=8.391 \AA$ Á. The calculated lattice parameters of cobalt ferrite obtained by solid-phase synthesis without preliminary mechanical activation at a temperature of $1100{ }^{\circ} \mathrm{C}$ coincide with the literature data (Table 2). Cobalt ferrite obtained by solid-phase synthesis with preliminary mechanical activation of the initial components has slightly distorted lattice parameters (Table 2). Obviously, mechanical activation leads to the formation of cobalt ferrite with a defective structure, as further indicated by calculation of root-mean-square microstrain, for which the value for samples obtained using mechanochemical synthesis is 2-3 times higher than that of the sample obtained by conventional solid-phase synthesis (Table 2).

The average crystallite size, determined from the values of the X-ray reflections broadening, varied in the range of 175 to $299 \AA$ Á depending on the calcination temperature of $300-450{ }^{\circ} \mathrm{C}$. The data given in Table 2 indicate that with an increase in the synthesis temperature, the perfection of the crystal structure also increases, and the broadening of the diffraction lines of the samples synthesized at high temperatures relates mainly to the small size of the crystallites (about 20-30 nm).

The important characteristics of catalytic systems are specific surface area and porosity. An increase in the synthesis temperature leads to a decrease in these parameters (Table 2). The isotherms of nitrogen adsorption/desorption of samples obtained by mechanical activation are shown in Figure 7a-c. These isotherms can be attributed to type IV; such isotherms are characteristic of bodies that have predominantly transitional pores (mesopores) according to Dubinin's classification; that is, pores with a diameter of tens to hundreds of angstroms [34]. A sample calcined at $350{ }^{\circ} \mathrm{C}$ has only mesopores with an average diameter of 3.5 to $29.4 \mathrm{~nm}$. According to estimation, $71.92 \%$ of the total pores fraction has a diameter of 5.9 to $14.9 \mathrm{~nm}$ (Figure 7a).

With an increase in the calcinations temperature, a decrease in the specific surface area and the total pore volume is observed (Table 2), which is associated with the gradual sintering of the samples, as a result of which the particles become coarse and form larger and more tightly interconnected aggregates from them. 

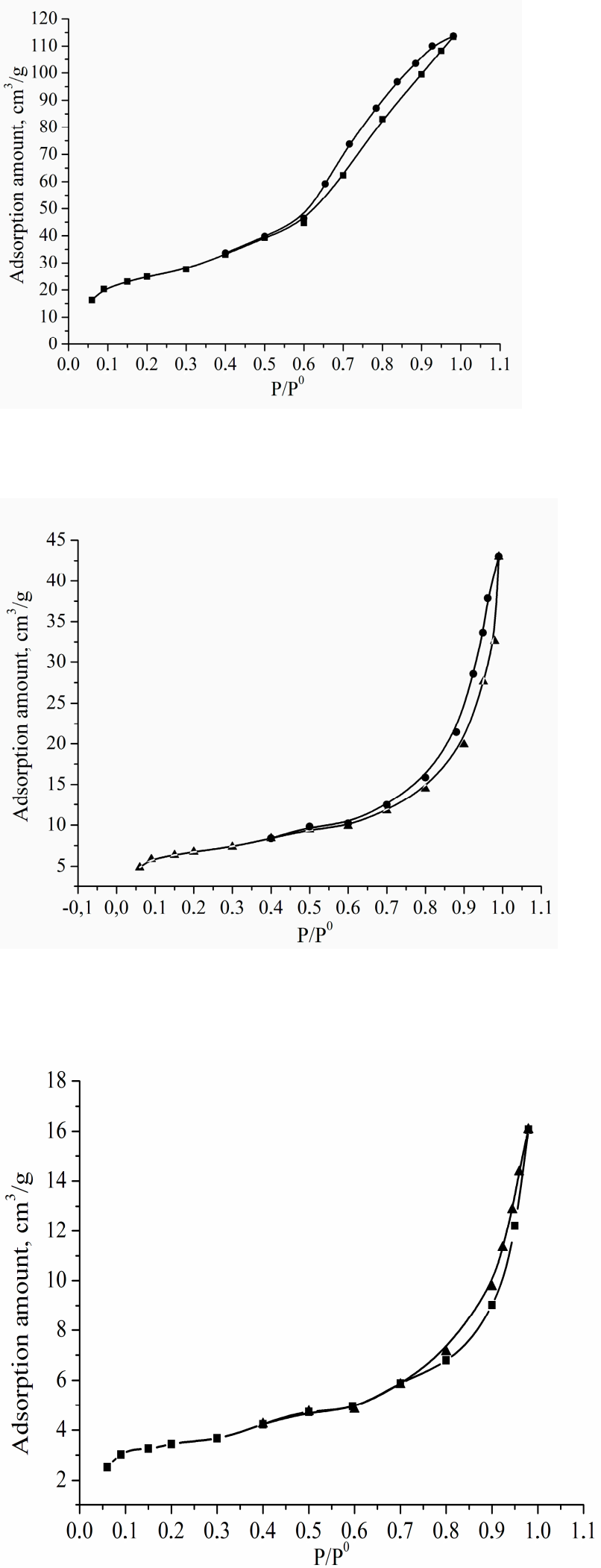

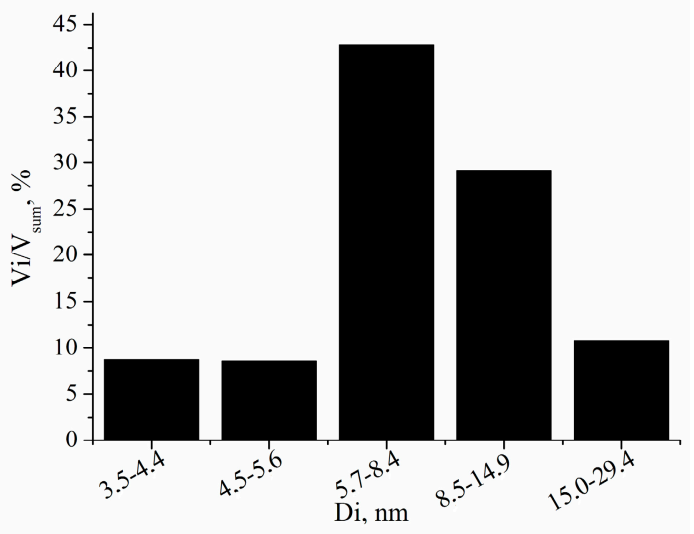

(a)

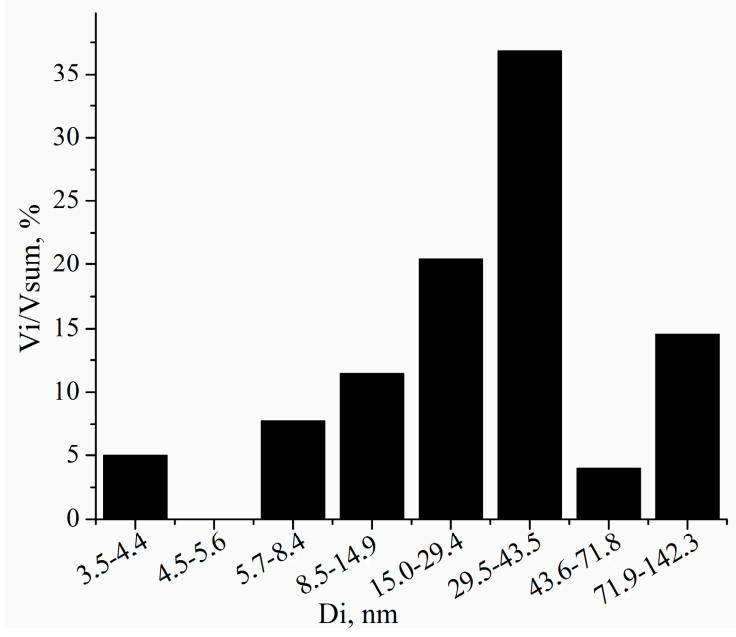

(b)

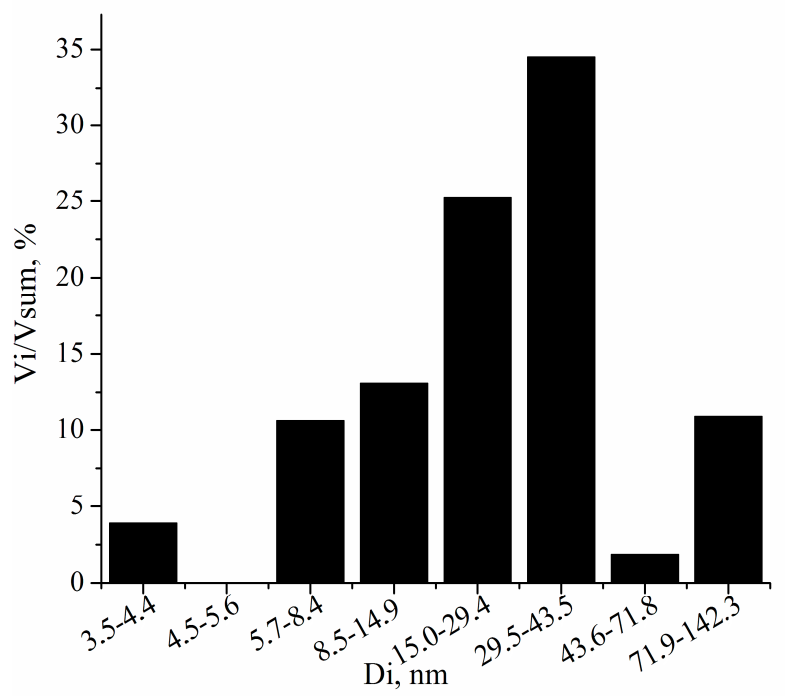

(c)

Figure 7. Isotherms of nitrogen adsorption/desorption on cobalt ferrite samples and the corresponding pore size distributions. Heat treatment temperature, ${ }^{\circ} \mathrm{C}:(\mathbf{a})-300,(\mathbf{b})-400,(\mathbf{c})-450$. 
An increase in the calcination temperature to $400-450{ }^{\circ} \mathrm{C}$ leads to an increase in the content of larger mesopores and the appearance of macropores (Figure $7 \mathrm{~b}, \mathrm{c}$ ). For example, a sample calcined at $400{ }^{\circ} \mathrm{C}$ has pores with a diameter from 15 to $43.6 \mathrm{~nm}$. They make up $57.29 \%$ of the total fraction of pores (Figure $7 \mathrm{~b}$ ). With an increase in the calcination temperature, a decrease in the specific surface area and total pore volume are observed (Table 2). It is associated with the gradual sintering of the samples. As a result, the enlargement of particles takes place and the larger and tightly interconnected aggregates are formed. It is established that the sample obtained without the use of mechanochemical treatment has a very low specific surface area of $0.6 \mathrm{~m}^{2} / \mathrm{g}$ and is non-porous. This is confirmed by the SEM images of this sample, which show that the powder particles have a smooth surface and grow into dense aggregates that do not have pores (Figure 6c).

\subsection{Catalytic Properties of Cobalt Ferrite}

Under the best conditions, the activity of the catalyst depends on the number of active sites per unit mass of the active component. Mechanochemical synthesis provides quantitative yield in a relatively short reaction time, in contrast to solid-phase interaction. In the case of solid-phase interaction, the catalyst has a high temperature of synthesis $500{ }^{\circ} \mathrm{C}$, hydration, sorption and low catalytic activity of $\mathrm{N}_{2} \mathrm{O}$ decomposition reaction. As a result, processes with mechanochemical activation are usually cost-effective and make it possible to obtain materials with high mechanical strength, a degree of homogeneity, and a low catalyst start-up temperature $250^{\circ} \mathrm{C}$.

Studies on the catalytic activity in the decomposition of nitrous oxide show a clear correlation between the specific surface of the samples and the degree of $\mathrm{N}_{2} \mathrm{O}$ decomposition (Figure 8). The maximum degree of decomposition is observed for the sample obtained by calcining the mechanically activated mixture at $350{ }^{\circ} \mathrm{C}$. The degree of $\mathrm{N}_{2} \mathrm{O}$ decomposition at $475{ }^{\circ} \mathrm{C}$ is $98.10 \%$. The catalytic activity of the sample calcined at $450{ }^{\circ} \mathrm{C}$ under the same conditions is significantly lower (the degree of $\mathrm{N}_{2} \mathrm{O}$ decomposition is only $12.87 \%$ ) Thus, one can state that the observed dramatic activity decrease from the calcination temperature increase from 400 to $1000{ }^{\circ} \mathrm{C}$ was due to the decomposition of the spinel structure. In other words, it was due to the disappearance of the $\mathrm{Co}^{3+}-\mathrm{Co}^{2+}$ redox couple necessary for $\mathrm{N}_{2} \mathrm{O}$ decomposition. Further increase in the calcination temperature of the sample to $1100{ }^{\circ} \mathrm{C}$ leads to reduction of $\mathrm{N}_{2} \mathrm{O}$ decomposition up to $7.5 \%$ at $550{ }^{\circ} \mathrm{C}$. It should be noted that monophase cobalt ferrite during solid-phase synthesis is formed at temperatures of $1000-1100{ }^{\circ} \mathrm{C}$. Its activity $\left(\mathrm{X}_{\mathrm{N} 2 \mathrm{O}}=5.5 \%\right.$ at temperature $\left.550{ }^{\circ} \mathrm{C}\right)$ in the decomposition of nitrogen oxide (I) is close in value to the sample obtained by mechanochemical synthesis and further heat treatment at $1100{ }^{\circ} \mathrm{C}$.

The mechanism of the reaction between $\mathrm{N}_{2} \mathrm{O}$ and the catalysts' active centers is generally thought to be a charge transfer from the catalyst to the vacant orbitals of $\mathrm{N}_{2} \mathrm{O}$, which destabilizes the $\mathrm{N}-\mathrm{O}$ bond and leads to bond breaking [35-38]. Therefore, electron charge transfer from the metal ion to the $\mathrm{N}_{2} \mathrm{O}$ molecule is a crucial step for $\mathrm{N}_{2} \mathrm{O}$ decomposition [35-38]. Electron transfer occurs from a low oxidation state metal cation, which subsequently increases its oxidation state. The possibility of the ion reduction from a high to a low oxidation state is also important for the regeneration of the active centers. Hence, the activity of the $\mathrm{Co}_{3} \mathrm{O}_{4}$ oxide spinel is attributed to the coexistence of a $\mathrm{Co}^{2+} \rightarrow$ $\mathrm{Co}^{3+}$ ion pair because of an easy one-electron transfer between these ions during $\mathrm{N}_{2} \mathrm{O}$ decomposition, as shown in the following mechanism [35-38]:

$$
\begin{gathered}
\mathrm{N}_{2} \mathrm{O}_{(\mathrm{g})}+\mathrm{Co}^{2+} \rightarrow \mathrm{N}_{2} \mathrm{O}^{-}{ }_{\text {(ads.) }} \ldots \mathrm{Co}^{3+} \\
\mathrm{O}^{-}{ }_{\text {(ads.) }} \ldots \mathrm{Co}^{3+} \rightarrow \mathrm{O}_{2(\mathrm{~g})}+\mathrm{Co}^{2+}
\end{gathered}
$$

As earlier studies of catalysts based on ferrites showed [39], the presence of oxygen, water, and nitrogen in the reaction gas mixture resulted in blocking of the catalyst active sites and a shift in the temperature of the onset of decomposition towards higher temperatures. 


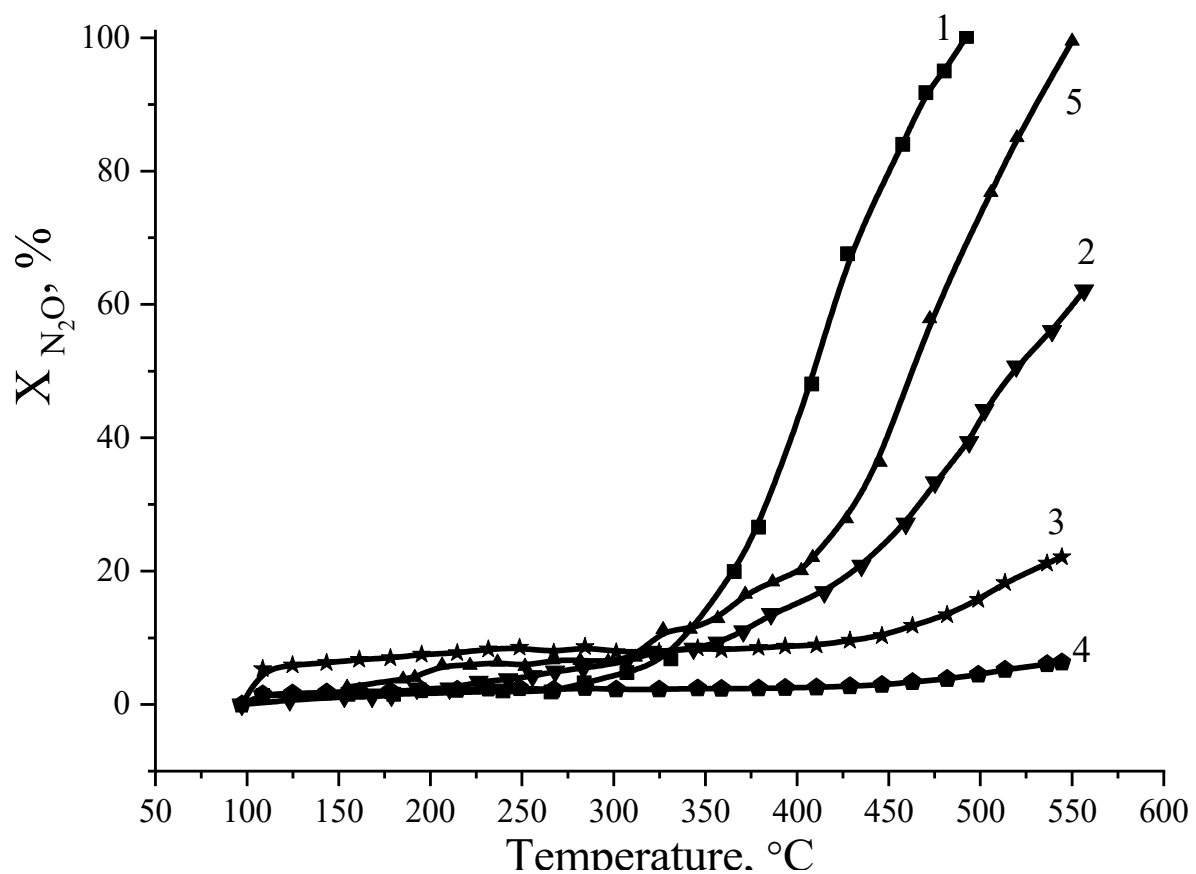

Figure 8. The effect of temperature on the degree of $\mathrm{N}_{2} \mathrm{O}$ decomposition. Calcination temperatures, ${ }^{\circ} \mathrm{C}: 1-350 ; 2-400 ; 3-450 ; 4-1100 ; 5-A V C-10$.

In the available publications, the authors test catalysts under different conditions $\left(\mathrm{N}_{2} \mathrm{O}\right.$ content, gas space velocity, and others). All these parameters affect the catalytic activity. The AVC-10 alumina-vanadium catalyst used in large-scale nitric acid production (stage of gas purification from nitrogen oxides) was chosen as the object of comparison. It was found that the degree of decomposition of $\mathrm{N}_{2} \mathrm{O}$ increases with the temperature increase, and it is $\%$ at $550{ }^{\circ} \mathrm{C}$. The specific surface area of the AVK-10 catalyst is $158 \mathrm{~m}^{2} / \mathrm{g}$, and the best sample of cobalt ferrite is $78.9 \mathrm{~m}^{2} / \mathrm{g}$. Obviously, during the decomposition of $\mathrm{N}_{2} \mathrm{O}$, not only the size of the catalyst surface area has an influence, but also the valence of the active catalyst component. For vanadium oxide $\mathrm{V}_{2} \mathrm{O}_{5}$, the activity is much lower than for cobalt ferrite.

This can be explained by a change in the mechanism of the catalytic reaction, since vanadium has a higher valence.

In this case, decomposition occurs with isolated transition metal ions $\left[\mathrm{V}^{5+}\right]$ :

$$
\begin{gathered}
\mathrm{N}_{2} \mathrm{O}+\left[\mathrm{V}^{5+}\right] \rightarrow \mathrm{N}_{2}+\left[\mathrm{V}^{5+}\right] \mathrm{O} \\
\mathrm{N}_{2} \mathrm{O}+\left[\mathrm{V}^{5+}\right] \mathrm{O} \rightarrow \mathrm{N}_{2}+\mathrm{O}_{2}+\left[\mathrm{V}^{5+}\right]
\end{gathered}
$$

It can be assumed that this catalyst also undergoes thermal decomposition due to the adsorption of $\mathrm{N}_{2} \mathrm{O}$ in the pores of the catalyst support- $\left(\mathrm{Al}_{2} \mathrm{O}_{3}\right)$.

\section{Materials and Methods}

\subsection{Raw Materials}

All reagents were commercially available and were used without further purification.

Cobalt oxalate $\left(\mathrm{CoC}_{2} \mathrm{O}_{4} \cdot 2 \mathrm{H}_{2} \mathrm{O}\right)-99.5$ wt. \%, $\left(\mathrm{Fe}_{2} \mathrm{O}_{3}-0.25\right.$ wt. \%, $\mathrm{NiO}-0.15$ wt. \%, and $\mathrm{CuO}-0.10 \mathrm{wt}$. \%, as impurities). The particle size of cobalt oxalate is up to $25 \mu \mathrm{m}$ (Figure 1 (a));

Iron oxalate $\left(\mathrm{FeC}_{2} \mathrm{O}_{4} \cdot 2 \mathrm{H}_{2} \mathrm{O}\right)-99.0$ wt. \%, $\left(\mathrm{Fe}_{2} \mathrm{O}_{3}-0.32\right.$ wt. \%, $\mathrm{CaO}-0.25$ wt. \%, $\mathrm{MgO}-0.23$ wt. $\%$ and $\mathrm{K}_{2} \mathrm{O}-0.2$ wt. $\%$ as impurities). The particle size of iron oxalate is up to $100 \mu \mathrm{m}$ (Figure 1 (b)). 
The industrial catalyst for selective reduction of NOx AVC-10 is used as an object of comparison of catalytic properties. This type of catalyst is used in industrial units for the production of nitric acid at the stage of gas purification from nitrogen oxides.

The main characteristics of the catalyst:

The composition of the catalyst is $\mathrm{Al}_{2} \mathrm{O}_{3}-98 \% \mathrm{wt}$., $\mathrm{V}_{2} \mathrm{O}_{5}-10 \% \mathrm{wt}$.

The catalyst surface area is $158 \mathrm{~m}^{2} / \mathrm{g}$.

Total pore volume- $177, \mathrm{~cm}^{3} / \mathrm{g}$.

\subsection{Samples Preparation}

The following methods were used for cobalt ferrite preparing: Solid-phase synthesis and joint mechanical activation.

Solid-phase synthesis. A mixture of cobalt oxalate and iron oxalate in a molar stoichiometric ratio was heat treated in a muffle furnace at the temperature range of $300-1100{ }^{\circ} \mathrm{C}$ for $4 \mathrm{~h}$.

Joint mechanical activation. A mixture of cobalt oxalate and iron oxalate in a molar stoichiometric ratio was mechanochemically treated for $45 \mathrm{~min}$ and then heat treated at the temperature range of $300-450{ }^{\circ} \mathrm{C}$. Mechanochemical treatment was carried out in a roller-ring vibrating mill VM-4. The diameter of grinding chamber, total volume of the chamber, oscillation frequency, amplitude, mass of grinding bodies, and mass of the loaded material were $98 \mathrm{~mm}, 0.302 \mathrm{~L}, 930 \mathrm{~min}^{-1}, 10 \mathrm{~mm}, 1194 \mathrm{~g}$, and $50 \mathrm{~g}$, respectively.

\subsection{Testing Procedures}

Powder X-ray diffraction (XRD) spectroscopy. The patterns were recorded on DRON$3 \mathrm{M}$ (Russia) X-ray diffractometer. The $\mathrm{CuK} \alpha$ radiation $(\lambda=0.15406 \mathrm{~nm}$, Ni filter) was used with a power supply $-40 \mathrm{kV}$ and $20 \mathrm{~mA}$, scanning rate $-2 \% / \mathrm{min}$, initial slit $-2 \mathrm{~mm}$, detector slit $-0.25 \mathrm{~mm}$.

Thermogravimetry (TG) and differential scanning calorimetry (DSC). The measurements were provided by the STA 449 F3 Netzsch (Germany) device under air atmosphere. The heating rate $-5{ }^{\circ} \mathrm{C} / \mathrm{min}$.

The surface area was determined by the BET method for low-temperature adsorptiondesorption of nitrogen. The measurements were provided by the Sorbi-MS (Russia) device. Before the test, the samples were dried in a nitrogen stream at a temperature of $250{ }^{\circ} \mathrm{C}$ for $60 \mathrm{~min}$.

Scanning electron microscopy (SEM). Microphotographs were provided by the Vega 3 Tescan device (Czech Republic).

Catalytic activity. Samples were tested in a $\mathrm{N}_{2} \mathrm{O}$ decomposition test. The tests were carried out using the catalytic complex PKU-2VD (Russia), the volumetric gas velocity was $20,000 \mathrm{~h}^{-1}$. The composition of the reaction gas mixture was used according to the $1 \%$ mass. $\mathrm{N}_{2} \mathrm{O}$ and $99 \%$ mass. $\mathrm{N}_{2}$. The temperature in the reactor ranged from 100 to $550{ }^{\circ} \mathrm{C}$. Gas chromatograph Krystallux 4000 M (Russia) with thermal conductivity detectors was used for analysis of the reaction products. Columns with $\mathrm{NaX}$ and HayeSep $\mathrm{Q}$ adsorbents were used to separate the gas mixture. The temperature in the columns was $65^{\circ} \mathrm{C}$.

\subsection{Qualitativex-Rayanalysis}

The interplanar distances $(d)$, the dimensions of the coherent scattering region (CSR) were calculated from XRD data.

The identification of crystalline phases on the diffractograms was carried out by comparing the calculated interplanar distances with those given in the ASTM database. The interplanar distances were calculated according to the Bragg equation [40]:

$$
d=\lambda / 2 \sin \Theta,
$$


where $\lambda$ is the wavelength(nm), $\Theta=X_{c} / 2$ is the diffraction angle, calculated as the gravity center position of reflex [41]:

$$
X_{c}=\frac{\int_{-\infty}^{+\infty} I(\vartheta) d \vartheta}{I_{\max }} \text { или } X_{c}=\frac{\sum_{i=1}^{N-1}\left(I_{i}+I_{i+1}\right) \Delta \vartheta}{2 I_{\max }},
$$

where $I$ is the intensity at the diffraction angle $\vartheta$ and $I_{\max }$ is the maximum intensity.

The dimension of coherent scattering region (CSR) was calculated using the modified Scherrer's equation [42], after linearization:

$$
\beta_{p h} \cos \Theta=\lambda / D_{S C R}+4 \varepsilon \sin \Theta,
$$

where $D_{S C R}$ is the dimension of the coherent scattering region, $e$ is the value of the relative mean square microdeformation (MD), $\beta_{p h}$ is the integral physical broadening of the $\mathrm{X}$-ray sample profile, calculated using the Gaussian's function [43]:

$$
\beta_{s}^{2}=\beta_{p h}^{2}+\beta_{i n s t}^{2}
$$

where $\beta_{s}^{2}$ is the integral broadening of the $\mathrm{X}$-ray profile of the sample, $\beta_{\text {inst }}^{2}$ is the instrumental broadening. Broadening of the $\mathrm{X}$-ray profile of the etalon was used as instrumental broadening.

Integral broadening of X-ray profile was calculated by the equation [41]:

$$
\beta=\frac{\int_{-\infty}^{+\infty} I(\vartheta) \vartheta d \vartheta}{\int_{-\infty}^{+\infty} I(\vartheta) d \vartheta} \text { или } \beta=\frac{\sum_{i=1}^{N-1} I_{i} \vartheta_{i}}{\sum_{i=1}^{N} I_{i}},
$$

The interplanar distances and corresponding Miller's indices were used to calculate the unit cell parameters. For cubic syngony [32]:

$$
\frac{1}{d^{2}}=\frac{h^{2}+k^{2}+l^{2}}{a^{2}}
$$

where $d$ is the interplanar distance, $a, c$ are the unit cell parameters, $h, k, l$ are the Miller's indices.

Specific energy $(E)$ was calculated according to the method proposed in [44]. The specific energy is only pure energy that is applied from the grinding media to the powder. This value does not include the loss of energy in the various mechanical components of the mill.

\section{Conclusions}

Thus, the preliminary mechanochemical treatment of the initial components makes it possible to decrease the temperature of the synthesis of monophasic cobalt ferrite three times compared with the solid-phase interaction of ones that have not been preactivated. Since the formation of new phases does not occur during mechanochemical activation, it is obvious that the main channel of relaxation of the supplied energy is the accumulation of defects in the structure of iron and cobalt oxalates, which in turn leads to the intensification of their decomposition processes.

The high homogeneity of the system subjected to preliminary mechanochemical activation contributes to a more complete and intensive interaction of the formed iron and cobalt oxides, which can also cause a decrease in the synthesis temperature. Cobalt ferrite obtained by mechanochemical synthesis has a more developed specific surface and a porous structure, which is explained by more "soft" conditions of its synthesis. Studies on the catalytic properties in the nitrous oxide decomposition show that cobalt ferrite exhibits catalytic activity in this reaction. The growth of catalytic activity is observed at $325^{\circ} \mathrm{C}$. The catalytic properties of cobalt ferrite are correlated with its surface area and porosity. The higher the porosity and specific surface area, the greater the degree of $\mathrm{N}_{2} \mathrm{O}$ decomposition. 
Author Contributions: Conceptualization, A.A.I. and K.D.; methodology, J.S., R.R. and K.D.; validation, A.A.I., A.P.I. and N.G.; formal analysis, R.R., J.S., K.D. and A.A.I.; investigation, K.D. and J.S.; resources, K.D., A.A.I., R.R., J.S., A.P.I. and N.G.; data curation, A.A.I., R.R. and K.D.; writing-original draft preparation, K.D.; writing—review and editing, R.R., A.A.I., J.S., A.P.I. and N.G.; visualization, R.R.; supervision, N.G.; project administration, A.A.I., A.P.I. and R.R.; funding acquisition, N.G. All authors have read and agreed to the published version of the manuscript.

Funding: The work was funded by the project of the state assignment for the implementation of scientific research work (Topic No. FZZW 2020-0010).

Data Availability Statement: Data will be made available by authors on request.

Acknowledgments: When carrying out the research, the equipment of the Central Collective Use of the ISUCT was involved.

Conflicts of Interest: On behalf of all authors, the corresponding author states that there is no conflict of interest.

\section{References}

1. Al Lehyani, S.H.A.; Hassan, R.A.; Alharbi, A.A.; Alomayri, T.; Alamri, H. Magnetic Hyperthermia using Cobalt Ferrite Nanoparticles: The Influence of Particle Size. Int. J. Adv. Technol. 2017, 8, 1-6. [CrossRef]

2. López-Ortega, A.; Lottini, E.; Fernández, C.D.J.; Sangregorio, C. Exploring the Magnetic Properties of Cobalt-Ferrite Nanoparticles for the Development of a Rare-Earth-Free Permanent Magnet. Chem. Mater. 2015, 27, 4048-4056. [CrossRef]

3. Kaçar, C.; Dalkiran, B.; Erden, P.E.; Kiliç, E. An amperometric hydrogen peroxide biosensor based on Co3O4 nanoparticles and multiwalled carbon nanotube modified glassy carbon electrode. Appl. Surf. Sci. 2014, 311, 139-146. [CrossRef]

4. Tourinho, F.A.; Franck, R. Aqueous ferrofluids based on manganese and cobalt ferrites. J. Mater. Sci. 1990, 25, 3249-3254. [CrossRef]

5. Cabuil, V.; Dupuis, V.; Talbot, D.; Neveu, S. Ionic magnetic fluid based on cobalt ferrite nanoparticles: Influence of hydrothermal treatment on the nanoparticle size. J. Magn. Magn. Mater. 2011, 323, 1238-1241. [CrossRef]

6. Silva, J.B.; Diniz, C.F.; Lago, R.M.; Mohallem, N.D. Catalytic properties of nanocomposites based on cobalt ferrites dispersed in sol-gel silica. J. Non-Cryst. Solids 2004, 348, 201-204. [CrossRef]

7. Abraham, A.G.; Manikandan, A.; Vadivel, S.; Jaganathan, S.K.; Baykal, A.; Renganathan, P.S. Enhanced magneto-optical and photo-catalytic properties of transition metal cobalt $\left(\mathrm{Co}^{2+}\right.$ ions $)$ doped spinel $\mathrm{MgFe}_{2} \mathrm{O}_{4}$ ferrite nanocomposites. J. Magn. Magn Mater. 2018, 452, 380-388. [CrossRef]

8. Rafferty, A.; Prescott, T.; Brabazon, D. Sintering behaviour of cobalt ferrite ceramic. Ceram. Int. 2008, 34, 15-21. [CrossRef]

9. Khedr, M.; Omar, A.; Abdel-Moaty, S. Magnetic nanocomposites: Preparation and characterization of Co-ferrite nanoparticles. Colloids Surf. A Physicochem. Eng. Asp. 2006, 281, 8-14. [CrossRef]

10. Kim, Y.I.; Kim, D.; Lee, C.S. Synthesis and characterization of $\mathrm{CoFe}_{2} \mathrm{O}_{4}$ magnetic nanoparticles prepared by temperature-controlled coprecipitation method. Phys. B Condens. Matter 2003, 337, 42-51. [CrossRef]

11. Zhao, L.; Zhang, H.; Xing, Y.; Song, S.; Yu, S.; Shi, W.; Guo, X.; Yang, J.; Lei, Y.; Cao, F. Studies on the magnetism of cobalt ferrite nanocrystals synthesized by hydrothermal method. J. Solid State Chem. 2008, 181, 245-252. [CrossRef]

12. Zhao, D.; Wu, X.; Guan, H.; Han, E. Study on supercritical hydrothermal synthesis of $\mathrm{CoFe}_{2} \mathrm{O}_{4}$ nanoparticles. J. Supercrit. Fluids 2007, 42, 226-233. [CrossRef]

13. Meron, T.; Rosenberg, Y.; Lereah, Y.; Markovich, G. Synthesis and assembly of high-quality cobalt ferrite nanocrystals prepared by a modified sol-gel technique. J. Magn. Magn. Mater. 2005, 292, 11-16. [CrossRef]

14. Gul, I.; Maqsood, A. Structural, magnetic and electrical properties of cobalt ferrites prepared by the sol-gel route. J. Alloy. Compd. 2008, 465, 227-231. [CrossRef]

15. Massart, R. Magnetic Fluids and Process for Obtaining Them. U.S. Patent US4329241A, 11 May 1982.

16. Bensebaa, F.; Zavaliche, F.; L’Ecuyer, P.; Cochrane, R.; Veres, T. Microwave synthesis and characterization of Co-ferrite nanoparticles. J. Colloid Interface Sci. 2004, 277, 104-110. [CrossRef] [PubMed]

17. Ibrahim, A.M.; Mahmoud, M.M.; El-Latif, M.M. Microwave Synthesis of Cobalt-Ferrite Nano-Particles by Polyol Method. Process. Prop. Adv. Ceram. Compos. II 2010, 220, 17-26.

18. Fecht, H.-J. Nanostructure formation by mechanical attrition. Nanostruct. Mater. 1995, 6, 33-42. [CrossRef]

19. Manova, E.; Kunev, B.; Paneva, D.; Mitov, I.; Petrov, L.; Estournes, C.; D’Orléans, A.C.; Rehspringer, J.-L.; Kurmoo, M. MechanoSynthesis, Characterization, and Magnetic Properties of Nanoparticles of Cobalt Ferrite, $\mathrm{CoFe}_{2} \mathrm{O}_{4}$. Chem. Mater. 2004, 16, 5689-5696. [CrossRef]

20. Ennas, G.; Marongiu, G.; Marras, S.; Piccaluga, G. Mechanochemical route for the synthesis of cobalt ferrite-silica and iron-cobalt alloy-silica nanocomposites. J. Nanopart. Res. 2004, 6, 99-105. [CrossRef]

21. Berchmans, L.J.; Karthikeyan, R.; Helan, M.; Berchmans, S.; Sepelak, V.; Becker, K.D. Mechanochemical Synthesis and Electrochemical Characterization of Nano Crystalline Calcium Ferrite. Catal. Lett. 2011, 141, 1451-1457. [CrossRef] 
22. Magaeva, A.A.; Naiden, E.P.; Terekhova, O.G.; Itin, V.I.; Verchekov, K.A.; Stadnichenko, A.I.; Boronin, A.I. Mechanochemical synthesis, phase composition, structural parameters, and magnetic properties of manganese ferrospinels. Nanotechnol. Russ. 2013, 8, 495-501. [CrossRef]

23. Rumyantsev, R.; Il'In, A.A.; Denisova, K.O.; Il'In, A.P.; Volkova, A.V. Calcium Ferrite Structure Formation During Mechanochemical Interaction in the System $\mathrm{FeC}_{2} \mathrm{O}_{4} \cdot 2 \mathrm{H}_{2} \mathrm{O}-\mathrm{Ca}(\mathrm{OH})_{2}$. Glas. Ceram. 2017, 73, 374-377. [CrossRef]

24. Velinov, N.; Dimitrov, D.; Koleva, K.; Ivanov, K.; Mitov, I. Mechanochemical Synthesis and Characterization of Nanocrystalline Copper-Cobalt Ferrites. Acta Met. Sin. 2015, 28, 367-372. [CrossRef]

25. Manova, E.; Paneva, D.; Kunev, B.; Estournès, C.; Rivière, E.; Tenchev, K.; Leaustic, A.; Mitov, I. Mechanochemical synthesis and characterization of nanodimensional iron-cobalt spinel oxides. J. Alloy. Compd. 2009, 485, 356-361. [CrossRef]

26. Ramankutty, C.; Sugunan, S.; Thomas, B. Study of cyclohexanol decomposition reaction over the ferrospinels, $\mathrm{A}_{1-x} \mathrm{Cu}_{x} \mathrm{Fe}_{2} \mathrm{O}_{4}(\mathrm{~A}$ $=$ Ni or Co and $x=0,0.3,0.5,0.7$ and 1), prepared by 'soft' chemical methods. J. Mol. Catal. A Chem. 2002, 187, 105-117. [CrossRef]

27. Braga, T.P.; Sales, B.M.C.; Pinheiro, A.N.; Herrera, W.T.; Baggio-Saitovitch, E.; Valentini, A. Catalytic properties of cobalt and nickel ferrites dispersed in mesoporous silicon oxide for ethylbenzene dehydrogenation with $\mathrm{CO}_{2}$. Catal. Sci. Technol. 2011, 1, 1383-1392. [CrossRef]

28. Kooti, M.; Afshari, M. Magnetic cobalt ferrite nanoparticles as an efficient catalyst for oxidation of alkenes. Sci. Iran. 2012, 19, 1991-1995. [CrossRef]

29. Cota, H.M.; Katan, T.; Chin, M.; Schoenweis, F.J. Decomposition of dilute hydrogen peroxide in alkaline solutions. Nature 1964, 203, 1281. [CrossRef]

30. Prokof'Ev, V.Y.; Gordina, N.; Efremov, A.M. Synthesis of type A zeolite from mechanoactivated metakaolin mixtures. J. Mater. Sci. 2013, 48, 6276-6285. [CrossRef]

31. Rumyantsev, R.; Il'In, A.A.; Pazukhin, I.V. Influence of mechanical activation of molybdenum oxide on its catalytic activity in the reaction of the partial oxidation of methanol. Theor. Exp. Chem. 2011, 47, 41-44. [CrossRef]

32. Sepelak, V.; Becker, K. Mechanochemistry: From Mechanical Degradation to Novel Materials Properties. J. Korean Ceram. Soc. 2012, 49, 19-28. [CrossRef]

33. Swanson, H.E.; McMurdie, H.F.; Morris, M.C.; Evans, E.H.; Paretzkin, B. Standard X-ray Diffraction Powder Patterns; US Department of Commerce, National Bureau of Standard: Gaithersburg, MD, USA, 1953.

34. Gregg, S.J.; Sing, K.S.W.; Salzberg, H.W. Adsorption Surface Area and Porosity. J. Electrochem. Soc. 1967, 114, 313. [CrossRef]

35. Kapteijn, F.; Rodriguez-Mirasol, J.; Moulijn, J.A. Heterogeneous catalytic decomposition of nitrous oxide. Appl. Catal. B Environ. 1996, 9, 25-64. [CrossRef]

36. Zeng, H.; Lin, J.; Teo, W.; Wu, J.; Tan, K. Monoclinic $\mathrm{ZrO}_{2}$ and its supported materials $\mathrm{Co} / \mathrm{Ni} / \mathrm{ZrO}_{2}$ for $\mathrm{N}_{2} \mathrm{O}$ decomposition. J. Mater. Res. 1995, 10, 545-552. [CrossRef]

37. Abu-Zied, B.M. Nitrous Oxide Decomposition over Alkali-Promoted Magnesium Cobaltite Catalysts. Chin. J. Catal. 2011, 32, 264-272. [CrossRef]

38. Abu-Zied, B.M.; Soliman, S.A. Nitrous Oxide Decomposition Over $\mathrm{MCO}_{3}-\mathrm{Co}_{3} \mathrm{O}_{4}(\mathrm{M}=\mathrm{Ca}$, Sr, Ba) Catalysts. Catal. Lett. 2009, 132, 299-310. [CrossRef]

39. Rumyantsev, R.N.; Ilyin, A.A.; Babichev, I.V.; Ilyin, A.P. Decomposition of nitric oxide (I) on the ferrite with different crystal structures. Sci. Isr. Technol. Advant. 2014, 16, 1-5.

40. Jost, K. Röntgenbeugung in Kristallen; Akad. Vlg: Berlin, Germany, 1975; p. 404.

41. Ludwig, G. Untersuchungsmethoden zur Charakterisierung Mechanisch Aktivierten Festkörpern; Közdok Pubk.: Budapest, Hungary, 1978; pp. 113-198.

42. Giacovazzo, C.; Monaco, H.L.; Viterbo, D.; Scordari, F.; Gilli, G.; Zanotti, G.; Catti, M. Fundamentals of Crystallography; IUC-Oxford University Press: Oxford, UK, 1992.

43. Chatfield, C.; Wruss, W.; Maly-Schreiber, M.; Ekström, T. The use of X-ray diffraction peak-broadening analysis to characterize ground $\mathrm{Al}_{2} \mathrm{O}_{3}$ powders. J. Mater. Sci. 1985, 20, 1266-1274.

44. Heegn, H. On the connection between ultrafine grinding and mechanical activation of minerals. Aufbereit. Tech. 1989, 30, 635-642. 